A Program Evaluation of the Character Education Program at a Junior High

School in Saint Louis County

A Dissertation presented to the Faculty of the Graduate School at the University of Missouri-Columbia

In Partial Fulfillment of the Requirements for the Degree Doctor of Education

by PAUL E SHARP II

Dr. Paul Watkins, Dissertation Supervisor

December 2013 
The undersigned, appointed by the Dean of the Graduate School, have examined the dissertation entitled:

\section{A PROGRAM EVALUATION OF THE CHARACTER EDUCATION PROGRAM AT A JUNIOR HIGH SCHOOL IN SAINT LOUIS COUNTY}

Presented by Paul E. Sharp II,

A candidate for the degree of Doctor of Education,

And hereby certify that, in their opinion, it is worthy of acceptance.

Dr. Paul Watkins

Dr. Ruth Ann Roberts

Dr. Margaret Dalton

Dr. Sharon Gunn

Dr. Lisa Bertrand 


\section{A PROGRAM EVALUATION OF THE CHARACTER}

\section{DEDICATION}

To my mom, Viola M. Sharp, who made all of this possible, for her endless encouragement and patience. To my friends and family for their support, especially Tracy L. Pettitt for her energy and enthusiasm. And in loving memory of my dad, Paul E Sharp, and my best friend Belle. 


\section{ACKNOWLEDGEMENTS}

Sincere gratitude is hereby extended to the following how never ceased in helping until completion of the paper:

Dr. Paul Watkins for his unwavering guidance and support during this journey;

The dissertation committee for their insight and suggestions;

And for the unwavering moral, emotional and financial support of my friends and family. 


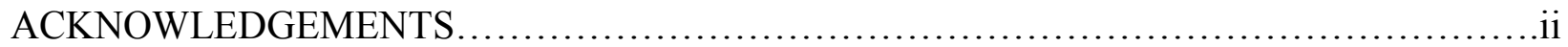

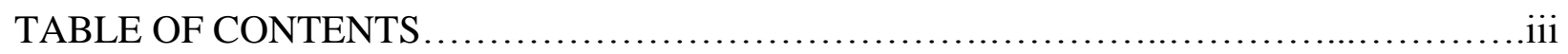

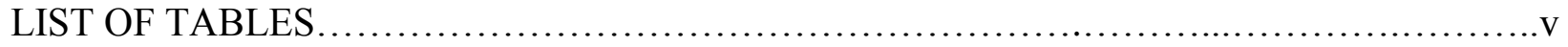

Chapter

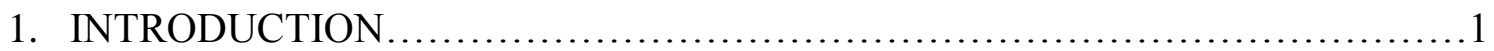

Conceptual Underpinnings for the Study....................................

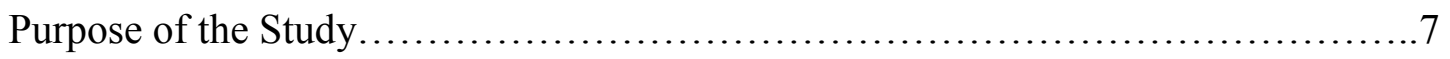

Statement of the Problem................................................. 8

Research Questions...................................................

Limitations and Assumptions............................................ 10

Definition of Key Terms.............................................. 10

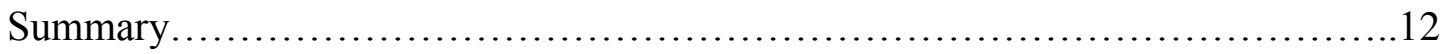

2. REVIEW OF RELATED LITERATURE ...................................14

Introduction.......................................................... 14

Character Education Defined.............................................. 14

History of Character Education......................................... 15

Revival of Character Education..........................................29

Implementation of Character Education.................................... 31

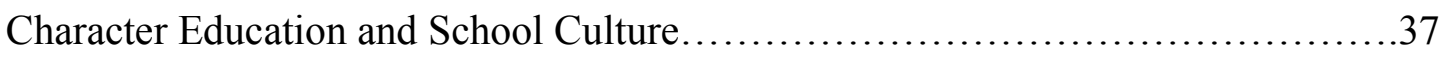

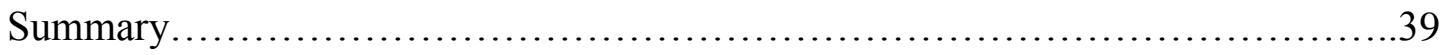

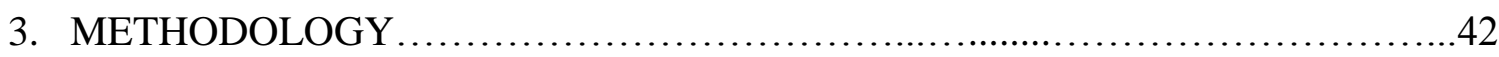

Purpose of the Study..................................................42 
Research Questions....................................................44

Population.................................................................. 45

Instrumentation........................................................ 46

Data Collection........................................................46

Data Analysis.......................................................47

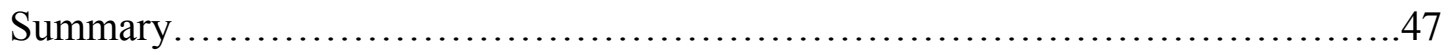

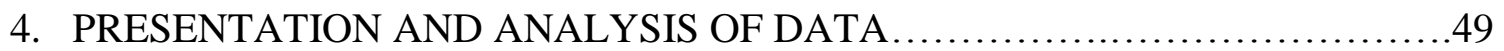

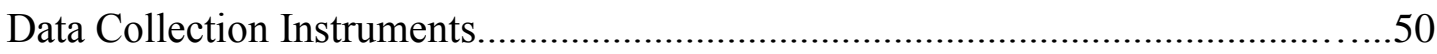

Data Analysis............................................................ 51

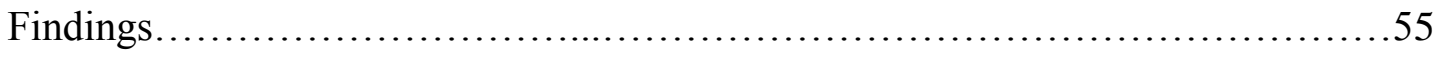

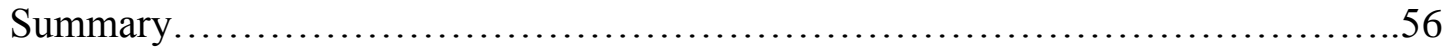

5. SUMMARY AND RECOMMENDATIONS ..................................57

Findings................................................................60

Conclusions..........................................................60

Limitations and Design Controls..........................................60

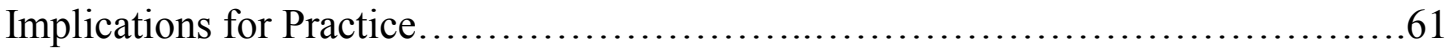

Recommendations for Future Research.....................................61

Bibliography.........................................................63

VITA........................................................................... 70 
A PROGRAM EVALUATION OF THE CHARACTER

\section{LIST OF TABLES}

Table 1 Demographic Population of Junior High School...................................52

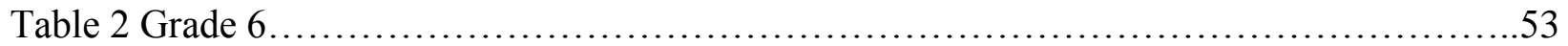

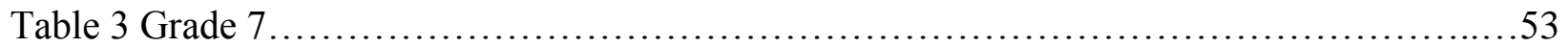

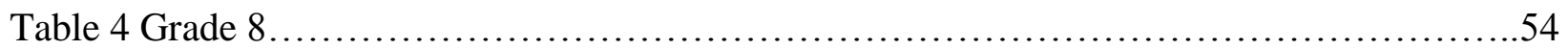

Table 5 Fighting and Bullying Referrals..........................................54

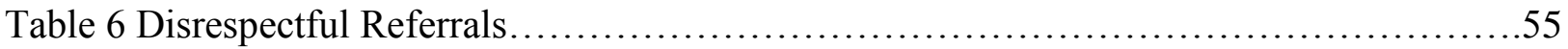

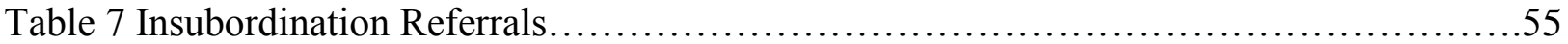




\section{A PROGRAM EVALUATION OF THE CHARACTER}

\section{ABSTRACT}

Starting with the Ancient Greeks, Pilgrims, Puritans and Quakers and now all school districts across the United States of America are faced with continually increasing challenges of developing students who are well-rounded human beings capable of making moral and ethical decisions in an ever-increasing immoral and unethical world (Lickona, 1996; Riley, 2001). The purpose of this program evaluation is to examine how association between student-to-student and student-to-teacher, which includes fighting and bullying, disrespect and insubordination, have been affected from the inception of a school-wide character education program to a national character education program recognition. A Pearson's Chi-square test of association was utilized because it is one of the most commonly used statistical approaches to repeated measures designs.

The scope of the program evaluation involved a cohort of students in a junior high school is St. Louis County from the inception of a character education program to the National School of Character recognition three years later. Discipline referrals were collected involving aggression, including fighting and bullying, disrespect and insubordination to determine the effect the character education program was having on student-to-student and student-to-teacher relationships. The result of the findings is there was no significant association between these reported behaviors, indicating the variables are independent of each other.

This program study indicates there is no significant limitation in the relationship involving discipline referrals from the inception of the character education to the national recognition. This leads to a conclusion that the national recognition may be less concerned about reduction in discipline referrals, and may put more weight on practice, procedures and policy. 


\section{CHAPTER ONE}

Introduction of the Study

Every school district across the United States of America is faced with continually increasing challenges of developing students who are well-rounded human beings capable of making moral and ethical decisions in an ever-increasingly immoral and unethical world (Lickona, 1996; Riley, 2001). Character education issues of moral and ethical development can be found in the early writings and beliefs of the Pilgrims, Puritans and Quakers. President Theodore Roosevelt summarized the issue of moral responsibility placed on public schools by his statement: "To educate a man in mind and not in morals is to educate a menace to society" (Lickona, 1996a, p.3).

As recognition of this educational and societal need, formal character education programs are being reinstituted within school districts across the country (Milson, 2000). Moreover, research is suggesting that the decline of formal character education in schools during the 1950s and 60s resulted in an increase in the focus on the individual rather than on the greater good (DeRoche \& Williams, 1998; McClellan, 1999). This individualized focus resulted in a rise in anti-social behavior, leading to such issues as increased youth violence, dishonesty, disrespect, bigotry, self-centeredness and a decline in overall work ethic (Lickona, 1996a).

The Character Education Manifesto presented by the Center for the Advancement of Ethics and Character (Ryan, Bohlin \&Thayer, 1996) stated the problem in this manner: "American schools have had from their inception a moral mandate. Moral authority, once vested firmly in both our schools and teachers, has receded 
dramatically over the past few decades. While many teachers are valiantly working to promote good character in their classrooms, many are receiving mixed and confusing messages as to what their role should be" (p. 1).

To counter a growing trend of increasingly disrespectful youth, a number of experts, researchers, state governments, boards of education and professional organizations called upon the nation and the nation's school districts to reinstitute character education. (McClellan, 1999; Milson, 2000). In his January 23, 1996, State of the Union Address, then President Bill Clinton challenged schools to "teach character education, teach good values and good citizenship." (Clinton, 1996) The comment by former President Bill Clinton was in response to a growing concern about the break-down of the traditional family in the United States, specifically the number of divorced and fatherless households.

William Bennett, Secretary of Education under President Ronald Reagan, called on schools to focus their attention on teaching the basic values many in society felt were lost; values of respect, responsibility, honesty, cooperation and perseverance were recognized as valuable (McClellan, 1992). Under intense pressure from the public and from local coalitions, two national organizations were formed as a result of this governmental insistence that character education be reinstated. These organizations were the Character Education Partnership and the Character Counts Coalition. Both organizations educate and look for ways to promote character education throughout the nation (Etzioni, 1995; Hayes, 1997; Lickona, 1996a; Riley, 2000). 
Of the two organizations formed, the Character Education Partnership took a leading role in the character education movement (Etzioni, 1995; Lickona, 1996a; Ries, 1999; Riley, 2000). Students learn as much or more from observing the behaviors of the adults within the school setting as they capture from the lessons presented in the classroom (Goldsmith-Conley, 1998). The probability of higher academic success is much greater in a school that has developed and nurtured a culture of cooperation, collaboration and respect among its staff and students, than in one that has not (Deal \& Peterson, 1999). “The nature of the relationship among adults who inhabit a school has more to do with the school's quality, character and the accomplishment of its pupils than any other factor" (Barth, 1990, p.513).

Schools that have made the effort to build a positive culture demonstrate far more than cooperation and collaboration among staff members. A culture is made up of shared assumptions between all individuals of a group and the unwritten rules governing the organization (Schein, 1992). It becomes essential to have a driving unity of purpose within a school for students and staff so that all know their shared mission and ultimately, the goals they are working toward (Gruenert, 1998). It is also vitally important to have established a sense of camaraderie, a place where collegial relationships and shared ideas are utilized to find solutions to problems. Ultimately, it is the adults within a school and their observable actions that determine the culture and character of the institution. Lasley (1997) discussed the importance of subtle social learning that students encounter when he stated,

"Our goal should be to become people of good character. That goal is achievable if we adults can see people as ends, not means; if we can see 
that people matter and need to be taken seriously and respected; and if we can see that we must be responsible as individuals for our own behavior" (p.655).

As mentioned before, William Bennett called on schools to focus their attention on teaching character education. Many in society felt the basic values such as respect, responsibility, honesty, cooperation and perseverance were lost (McClellan, 1992).

Thomas Lickona, a leading researcher in the field of character education, noted three reasons why it is important that schools engage in some sort of character education program. First, it is essential that people develop good character to become productive members of society. Second, schools are better places for young people when they have atmospheres of goodness and caring. An atmosphere of caring is also conducive to a positive learning environment. Finally, building character in students through wellplanned educational programs leads to individuals who have the capacity and desire to think and act morally as members of society. It becomes imperative, therefore, that schools take a leadership role in trying to infuse character education into the curriculum (Lickona, 1996a; Peterson \& Skiba, 2001).

Lickona's research has substantially supported the concept that without all stakeholders' commitment, no long-term change can occur and programmatic initiatives will flounder and ultimately fail (Lickona, 1996a). Therefore, in order to build a school environment centered on providing character education for its students, the school community -- teachers, secretaries and administrators -- must model the very traits its personnel are attempting to teach (Goldsmith-Conley, 1998; Lickona, 1996a; Ries, 1999). 


\section{Conceptual Underpinnings for the Study}

Lickona (1996a), while writing on behalf of the Character Education Partnership, noted that although there are a variety of methods to teach character education, there are eleven basic principles which guide the successful implementation of an effective character education program. These eleven principles are: promotion of core ethical values, a comprehensively defined set of character traits, a comprehensive approach to character education, the school seen as a caring community, opportunities are given for moral action, a meaningful and challenging curriculum is established, development of intrinsic motivation, caring staff and moral community, students and staff demonstrate moral leadership, the community is a partner in character education and the character education initiative is assessed. These eleven principles are supported throughout much of the research on character education (DeRoche \& Williams, 1998; Lickona, 1996a; McKay, 2002; Ries, 1999).

The Cooperating School Districts used these eleven principles to develop their ten essentials for the development and implementation of an effective character education program (Cooperating School District, 2002). The Cooperating School District closely aligned its ten essentials: community participation, character education policy, identified and defined character traits, an integrated curriculum, experiential learning, evaluation, adult role models, staff development, student leadership and sustaining the program, with the Character Education Partnership's eleven principles (Cooperating School District, 2002). While each of the eleven principles and ten essentials is equally important, many of them center on the behavior of members of the school community. Both the ten essentials and eleven principles help us demonstrate the formulation of a culture within 
the school itself. Items such as building a caring community within the school, shared responsibility for the character education of all students and staff, as well as the parents and community in which the school exists, are imperative to successful character education programs. The school-wide community should model positive character traits for all students, clearly focused on what type of culture has been established within the school (Lickona, 1996a).

Demonstrating an environment that is a caring place for students to learn, grow and be nurtured is a necessary piece of effective character education. Research has shown that students who feel comfortable and safe in their environment demonstrate positive attitudes which expedite the learning and teaching process (Peterson \& Skiba, 2001). Also, students must embrace the ideology of caring for each other and championing the cause of those who find it difficult to stand up for them self. Bulach maintained that bullying behavior can be greatly reduced if actions of forgiveness, sympathy and kindness are openly practiced (Bulach, 2002). Adult role models should demonstrate that the school is willing to provide compassion for everyone (Ryan \& Bohlin, 2001).

Research has also shown a necessity of having all stakeholders, including parents and community, be responsible for character education. DeRoche \& Williams stated, “...character education is a planned effort by the whole community, through its institutions (principally the schools), to assist children and youth in becoming morally literate adults," (1998, p. 24).

Several researchers address the importance of appropriate modeling behaviors within a school. Goldsmith-Conley (1998) stated, "We lack, however, enough educators who are aware of the power and nature of school culture and how decisions determine 
this culture and its subsequent effect on the behavior and character of its participants" (p.49). McGill (2001) believed that daily expression of subtle messages sent by schools to its students display what is important and how things are said and done is just as important as any formal implementation of character education curriculum. McGill termed this subtle approach "hidden curriculum." Freado (1997) also stated it in this manner, "The hidden curriculum might manifest itself in school rules and standards for student behavior, teacher conduct and or leadership. And, though it is much less tangible, it can have a major impact on the lives and learning of students" (p.10).

McGill (2001), writes that an effectively implemented character education program can make a school a more positive, productive place for students to learn, therefore improving the culture and academics of a school. Purpose of the Study

Although there have been many studies conducted on character education and social interactions in middle/junior high schools, the relationship, for the purpose of this study, is defined as student-to-student and student-to-teacher. The purpose of this program evaluation is to realize how relationships between student-to-student and student-to-teacher, which include bullying and fighting, disrespect and insubordination, have been affected from the inception of a school-wide character education program to being recognized as a National School of Character. As a point of interest for the reader: $73.9 \%$ of the population is identified as white/Caucasian, within that category, $35 \%$ are Bosnian. 11.5\% are black/African American. 11.9\% students are identified as Asian, mostly from Vietnam and the remaining $2.7 \%$ of the students identify themselves as Latino/Latina. Furthermore, $64.4 \%$ of the students are eligible for free or reduced-price 
meals and an average of $95.8 \%$ of the students are in attendance and over 20 different languages are spoken by the caregivers and guardians (DESE, 2013). Taking the whole student population into account, females represent $46 \%$ and the males make up $54 \%$. The staff, including administrator and counselor, is predominately white/Caucasian at over $90 \%$. There is a 19 to 1 student/teacher ratio and a 261 to 1 student/administrator ratio. Statement of the Problem

More and more states continue to encourage and even demand schools to provide some type of character education training to students (DeRoche \& Williams, 1998). This is usually documented at the building and/or district in the school improvement plan. At least one state, Alabama, mandates that a specific amount of time should be spent on character education throughout the day (Ries, 1999). When investigating how to effectively implement such a program, research has shown that character education is most beneficial when implemented in a comprehensive, thoughtful and direct manner (Lickona, 1996, Berkowitz, 2000). It is imbedded into the curriculum, extracurricular and daily conversations. Effective implementation requires adult role models, community participation, student leadership and integrated curriculum traits that are well defined (McKay, 2002). Implementing character education can have positive results throughout a school as indicated by research (McGill, 2001). Researchers agree that for an implementation to be effective, a positive school culture is necessary (Goldsmith-Conley, 1998; Lasley, 1997; McGill, 2001).

The Character Education Partnership believes a school's culture must change for character education to be effectively implemented (Ries, 1999). This can consist of many factors, such as having positive adult role models; a collaborative work atmosphere; and 
collegiality among the students, staff and parents of the school (Deal \& Peterson, 1999; Lickona, 1996). As research has shown that a school's culture influences character education efforts, the question remains which specific factors of school culture have the most significant relationships to character education essentials? Likewise, what are the relationships between these factors and successful character education programs?

The problem identified for this study involves the effective implementation of a character education program by examining the resulting relationships among student-tostudent and student-to-teacher as measure by discipline referrals.

Research Questions

Research questions that arose from the problem and purpose of this program evaluation examine student-to-student and student-to-teacher relationships during the implementation of a nationally recognized character education program. The primary research questions examined in this study are as follows:

1. Has the character education program limited student-to-student and student-to-teacher fighting and bullying from inception of the character education program to national recognition as measured by discipline referral data?

2. Has the character education program limited student-to-student and student-to-teacher disrespect from the inception of the character education program to national recognition as measured by discipline referral data?

3. Has the character education program limited student-to-student and student-to-teacher insubordination from the inception of the program to national recognition as measure by discipline referral data? 
H1) There is no difference in the relationship as measure by discipline referral data.

H2) There is no difference in the relationship as measure by discipline referral data.

H3) There is no difference in the relationship as measure by discipline referral data.

Limitations and Assumptions

The limitations to this study are relative to geographical area and designs used by the researcher and are indicated as follows:

1) This study was limited by the validity and reliability of the instruments used.

2) The possibility of human error when entering the data into the software program.

3) This study was limited to three years of data.

4) Limited to one cohort of students.

5) This study was limited by the administration and teacher's level of conviction and comprehension of professional expectations and procedures.

Definition of Terms

Adult role models. The degree to which those adults involved in the character education initiative are positive role models (Cooperating School District, 1999). Aligned to the Character Education Partnership's Eleven Principles of Effective Character Education principles \#4 - The school is a caring community and \#9Staff and students demonstrate moral leadership (Lickona, 1996a).

Character education. "The form that any character education initiative takes must be directly related to the outcomes the institution hopes to achieve" (Berkowitz \& Fekula, 1999). For purposes of this study, character education will be defined as the teaching and modeling of character traits such as honesty, respect, 
responsibility and cooperation: moral and ethical values shared by society as "good" and correct behavior.

Integrated curriculum. The degree to which the character education initiative is integrated into the curriculum (Cooperating School District, 1999). Aligned to the Character Education Partnership's Eleven Principles of Effective Character Education principle \#6 - Effective character education includes a meaningful and challenging academic curriculum that respects all learners and helps them to succeed (Lickona, 1996a).

School culture. "The guiding beliefs and expectations evident in the way a school operates, particularly in reference to how people relate (or fail to relate) to each other" (Fullan \& Hargreaves, 1996, p.37).

Bullying. Intimidation or harassment of a student or multiple students perpetuated by individuals or groups. Bullying includes, but is not limited to: physical actions, including violence, gestures, theft, or damaging property; oral or written taunts, including name-calling, put-downs, extortion, or threats; threats of retaliation for reporting such acts; sending or posting harmful or cruel text or images using the Internet or other digital communication devices; sending or posting materials that threaten or raise concerns about violence against others, suicide or self-harm. Students will not be disciplined for speech in situations where the speech is protected by law.

Disrespect. -Verbal, written, pictorial or symbolic language or gesture that is directed at any person that is in violation of district policy or is otherwise rude, vulgar, defiant, considered inappropriate in educational settings or that materially 
and substantially disrupts classroom work, school activities or school functions. Students will not be disciplined for speech in situations where it is protected by law.

Fighting. - Mutual combat in which both parties have contributed to the conflict either verbally or by physical action.

Insubordination. - Not submissive to authority or following teacher/adult requests.

\section{Summary}

As mentioned before, Thomas Lickona noted three reasons why it is important that schools engage in some sort of character education program. First, it is essential that people develop good character to become productive members of society. Second, schools are better places for young people when they have atmospheres of goodness and caring. An atmosphere of caring is also conducive to a positive learning environment. Finally, building character in students through well-planned educational programs leads to individuals who have the capacity and desire to think and act morally as members of society. It becomes imperative, therefore, that schools take a leadership role in trying to infuse character education into the curriculum (Lickona, 1996a; Peterson \& Skiba, 2001).

Goldsmith-Conley (1998) stated that educators should be focusing on a school's culture when trying to develop character in students rather than a planned program. Lasley (1997) believed the social learning a student encounters and observes has a greater impact than character education curriculum. Many other researchers agree that aspects of a school's culture inevitably impact a school's character education effort (Berkowitz, 2000; Lasley 1997; Lickona, 1996a; McGill, 2001). 
The school discipline data is collected on a monthly basis and analyzed. Monthly data is then combined to provide an overall picture of the school year's discipline results. Three cohorts from 2007, 2008 and 2009 are the subjects of this analysis. The pre data was accumulated at the end of the cohorts' sixth grade year. The post data, on the same cohort, was collected at the end of the students' eighth grade year. The collection of data was focused in three areas or criteria: aggression, which includes fighting and bullying; disrespect and insubordination. The data collected were defined into student-to-student and student-to-teacher categories. Data was entered by an administrator or a designee based on written office discipline referrals. These office discipline referrals are written by teachers or other staff pertaining to a discipline issue concerning a student's actions and behavior.

In the next section, a comprehensive review and analysis of the literature relevant to character education, historical perspective and school culture is presented. Included in the third section will be information on the study design, procedures for collecting and analyzing quantitative data and information about the population, sample and instrumentation. In the fourth section will be a presentation of the findings of the quantitative data and an analysis of each of the research questions. In the final section, the researcher will include a summary of findings, conclusions, implications and recommendations for further research in the area of school culture and character education.

\section{CHAPTER TWO}

Review of Related Literature 
In order to fully investigate the purpose of this study, an evaluation of the character education program at a middle school, the literature review included research on character education and school culture. Within the area of character education, four areas were examined: the history of character education, the revival of character education, the factors impacting the implementation of a character education program and character education.

\section{Character Education Defined}

An expert in child development, Thomas Lickona, stated, “. . . character education is the deliberate effort to cultivate virtue - that is, objectively good human qualities that are good for the individual person and good for the whole society. That doesn't happen accidentally or automatically. It happens as a result of great and diligent effort" (2000, p.1). Moreover, character education can be defined as, "the long term process of helping young people develop good character, i.e., knowing, caring about and acting upon core ethical values such as fairness, honesty, compassion, responsibility and respect for self and others" (Berkowitz, 2000, p.2). While there are critics of teaching values and character in schools, according to DeRoche \& Williams (1998), teachers, administrators, parents and students should realize that

...they have ethical responsibilities to one another and that, at heart, education is a moral enterprise; that the malleable years of our children's youth are short and crucial; that what is learned and what is not learned is important; that what becomes habit and what does not become habit will have great consequences for the student and, of course, that what one 
comes to believe is good and right and just will be central to how one lives out one's life (p. x).

Defining character education has emerged from a long history of ethical values dating back several centuries. School culture meanwhile is defined as "the guiding beliefs and expectations evident in the way a school operates, particularly in reference to how people relate (or fail to relate) to each other" (Fullan \& Hargreaves, 1996, p.37). Understanding a school's culture can help the staff to develop a more effective school for all of its students (Gruenert, 1998). The culture of the school organization must be considered when discussing the establishment of a character education program. Schein (1992) defined organizational culture as,

A pattern of shared basic assumptions that the group learned as it solved its problems of external adaptation and internal integration that has worked well enough to be considered valid and, therefore, to be taught to new members as the correct way to perceive, think and feel in relation to those problems (p. 12).

How a school operates affects the educational climate, which ultimately impacts the academic achievement of its students. As a result, school culture cannot be ignored when looking at the effectiveness of character education (McGill, 2001).

History of Character Education

Within the last quarter century, the teaching of character in schools has become as important as teaching writing, mathematics and reading. The word character derives from the Greek word "charosso", "to mark" or "to engrave", which harkens to the works and writings of Plato and Aristotle (Bennett, 1988; Benninga \& Minkler, 1997; Benninga \& 
Wynne, 1998; Close, 1997; Heft, 1995; Lickona, 1998; Salls, 2007). It was the Ancients' way of addressing character education at that time. These philosophers were concerned with the development of virtues such as honesty, courage, perseverance, civic virtue, respect, responsibility and trustworthiness (Bennett, 1988; Benninga \& Minkler, 1997; Benninga \& Wynne, 1998; Close, 1997; Lickona, 1996a; Salls, 2007). The tablet writings and scripts of philosophers and theologians continued to be the means of disseminating information on character and moral values into the early $15^{\text {th }}$ century (Benninga $\&$ Wynn, 1998).

The sixteenth century brought differing groups of Europeans to colonize the New World. These settlers carried with them complex and different beliefs and philosophies on the rearing of children and on the subject of character education (McClellan, 1999). These views reflected the nationalities, religions and cultures of the different European regions. By far the most influential group in the development of character education in young people was the various sects of Protestants coming to the New World (McClellan, 1999; Salls, 2007). There were three distinct groups of settlements: the Puritans had settled in New England and were Calvinists, the Southern settlers belonged to the Church of England, founded by Henry VIII and the Middle colony settlers were from Holland and the Dutch Reformed Church.

The Puritans left England to found and establish a community free from the constraints and domination of the Church of England. The Puritans believed that salvation was through scripture and "God was demanding and children needed to be trained in self-denial, in rigorous discipline and, above all else, in family - principally by reading the Bible" (Salls, 2007, p.5). Puritan children were reared in a strict environment 
with obedience to authority. The Puritans' belief was embodied by a society dedicated to an intellectual heritage and pursuing an ideal culture. The family, school and church were all dedicated to molding the character of the person.

The Southern settlers, or Anglicans, brought with them to the New World a less intense attitude towards education and religion. Their children grew up with more affection from their parents. Families wanting more education hired private tutors within the home. A person's position in society was of upmost importance and character education was about respect and duty. Little attention was given by the government towards the establishment of structured schools.

The Middle settlers, or Quakers, were appropriately named not only for their geographical location, but also for their moderate and more tolerant religious views. ". . . they taught their children to control passion through reason, virtue and piety" (Salls, 2007, p.6). Overall, Quakers showed little interest in primary education and just like their Northern and Southern counterparts, the bible was used the basic tool to learn to read (McClellan, 1992; Salls, 2007). Moreover, settlers were allowed complete religions freedom and had local authority to accommodate each denomination by granting education and religious decisions.

In America during the seventeenth century, parents continued to pray with their children and instruct them in their particular religious faith, teach and demonstrate moral and civic virtues and foster good behavior (Benninga \& Wynne, 1998; McClellan, 1999; Salls, 2007). Although this type of disciplined approach varied in presentation and intensity according to the religious teachings of the community, it was agreed that faith and virtue were seen as the backbone of a person's character and were mentioned 
frequently in biblical teachings (McClellan, 1999). During this time period there also is a softening tone of moral education. This softening can be attributed to the establishment of a stable and prosperous country. According to McClellan, "At the root of the new moral tone was the extraordinary stability of family and community life in the towns, cities and plantations along the eastern seaboard where most Americans still lived" (1999, p.10). Parents had more confidence in their societies and communities, thus resulting in a loss of hardline morality and rigid religious expectations.

Although the early colonists did not have structured schools in the first half of the 1600 's, this began to change in 1642. In Massachusetts, the general court expressed concern about neglectful parents and masters in the rearing of their children. This ordinance gave constables the authority to fine and relocate neglected children to a location that would provide a proper education (McClellan, 1999).

During these early days in America, schools focused more on teaching character education than on the academic pursuits of their students (Greenawalt, 1996; Hunter, 2000; Lickona, 1993b). The Bible and the various religious catechisms were the primary references in public education for both moral and religious instruction (Greenawalt, 1996; Heft, 1995; Lickona, 1993b; McClellan, 1999). Hornbooks, designed to teach the alphabet and reading, were developed around the various catechisms of different religious sects (McClellan, 1999; Salls, 2007).

As the structure of traditional schooling started to take hold, eighteenth century colonial Americans did not change the fundamental way children were taught character education; what did change was the process in which it was presented (Hunter, 2000). Up to this point, children had been required to learn Biblical lessons at an early age. These 
lessons solidified the character their parents and communities wanted to instill in them. Now, many regions approached the education of their students in a more unstructured manner (McClellan, 1999). Because of these diverse societies "common schools" were created in many areas. Although created to teach the "secular" subjects, the "common school" still was heavily influenced by religious dogma, while the "Sunday School" focused strictly on the religious development of the young (Hunter, 2000; McClellan, 1999). Parent and community commitment to character education had not diminished. However, the confidence some people had in their communities and churches to effectively educate their students allowed for the quick forgiveness of the occasional bending of the moral rules (McClellan, 1999; Salls, 2007). Before the American Revolution, the overriding feeling on character education throughout the country was one of moderation (McClellan, 1999; Salls, 2007).

With the struggles the country faced during the fight for freedom, one would assume that the loosening of the societal hierarchy and the changes in thought regarding cultural and political restraints would lead to the relaxation of moral and character education throughout the country. In fact, the opposite was true. McClellan (1999) stated, "[society] moved in precisely the opposite direction... abandoning the relaxed style of the eighteenth century in favor of an insistence on rigid self-restraint, rigorous moral purity and a precise cultural conformity" (p.17). One example of this change is the passage of the Northwest Ordinance of 1787 by the country's first legislators. Written in the Ordinance the importance of religion and morality were cited as essential to good government and the happiness of mankind (Salls, 2007). 
The new focus in character education was in part due to the increased opportunities available to young people throughout the country. Because of the westward expansion of the country, the growth in economic possibilities in the industrial cities and the advancement of social classes that had previously not been afforded many opportunities, joined with a decline in the need for children to stay closely attached to their families longer into their life, led to the increased promotion of a strict moral upbringing in order to ward off the evils and temptations of the outside world (McClellan, 1999; Salls, 2007).

Due to the increased choices and decisions faced by adolescents and young adults at the turn of the century, there was an initiative to develop character education and moral development at an early age. In 1837, the Secretary to the Massachusetts Board of Education, Horace Mann, also known as the father of the common school, implemented a program in schools to encourage the development of reason and conscience in students at an early age by the daily recitation of Bible verses (Salls 2007). Mann believed the noblest goal of education concerned the development of moral character and he emphasized the teaching of virtue before knowledge. From 1830 through the 1860 's the prevalence of state school systems grew rapidly and a majority of children were expected to attend schools that focused on a strict moral upbringing (McClellan, 1999; Salls, 2007). Education with a strong religious foundation continued well into the twentieth century (McClellan, 1992; Salls, 2007).

This religious foundation was reinforced when William McGuffey introduced his popular McGuffey Readers. McGuffey taught reading and portrayed American history with biblical exhortations and heroic tales in his instructional books. While children 
practiced reading and arithmetic, they also learned lessons about honesty, love of neighbor, hard work, prudence, patriotism and courage (Salls, 2007). The hope for instilling this type of rigid moral education at such an early age was to develop a strong internal sense of direction in the child. The belief is that children would be less apt to listen to the misleading opinions of others and more willing to follow the values that they had internalized at an early age (McClellan, 1999; Salls, 2007).

Wave upon wave of European immigrants arrived on American shores during the first half of the nineteenth century. These immigrants were German, Irish, Polish and Italian and many were Catholic. Public schools' moral education programs, up to this point, were a generic form of traditional Protestant values. "Catholics felt that trying to teach morality without reference to religion would lead to religious indifference. . ." (Salls, 2007, p.10). In an attempt to diminish the divide between different religious groups and desire to establish a nonsectarian form of moral education, educational materials, such as the McGuffey Readers, underwent a major shift in their religious focus by removing most biblical references. The results of this nonsectarian movement had a far-reaching impact that is still being felt today (McClellan, 1999; Salls, 2007).

The original movement was designed to bring the major stakeholder religions together to create a uniform moral education program for the youth throughout the country at the time (Salls, 2007). While the supporters of this movement never intended to eliminate religious education completely, they did want to try to find common biblical convictions in order to create stability within the schools. The promoters of this effort did not have the foresight to see the strength of the religious convictions within the different factions of Protestants and Catholics. Trying to unite these complex and differing 
philosophies only increased the divide and hostilities among the churches (McKnight, 2003; Salls, 2007). The result of this was the widening and far-reaching spread of individual religious dogma and the establishment of more parochial schools unique to individual religions. As more religious schools were built, it became less likely the country would ever come to an agreement as to what was appropriate American public schooling (McClellan, 1999; Salls, 2007).

The other issue to come out of trying to develop a nonsectarian moral education program for all students was the eventual secularization of public schools. Early Protestant groups firmly believed that the way to teach students morals was through religious instruction in public schools (McKnight, 2003; Salls, 2007). Initially, state funding was used to support these endeavors. However, as the number of Catholic immigrants increased, resulting in more Catholic schools, a pattern of discrimination and inequity against Catholics began to appear. In an effort to restrict state funding from these new Catholic schools; Protestants had to show that they were taking a more secular stance in the academic instruction of students. Catholics were unwilling to relegate the authority of the church to only the private domain and did not agree with the state's autonomous role in character education. This stance only continued to widen the divide between Protestants and Catholics, as well as the parochial and public schools. What was meant to find common ground and unity during the late 1800 's instead created a nonsectarian public education which was a contributing cause of the eventual secularization of the public school system (McClellan, 1999; Salls, 2007). "Thus began the separation of character from religion in American public schools and in many people's minds. The definitive break did not come until 1963, when non-denominational 
prayer in public school was declared unconstitutional, violating the separation of Church and State" (Salls, 2007, p.10).

As Americans ushered in the twentieth century, public education in the United States started to move in a completely different direction. The increasingly modernized and industrialized society focused on mass production, creating vast changes in the working environment. With the increase in academic courses being offered to meet the rapidly changing needs of the workplace, less time was available for the traditional methods used to teach moral education. Due to this, schools looked for other ways to infuse and embed character into the curriculum (McClellan, 1999, Salls; 2007). In the 1800 's the primary role for character education rested with the family. Due to modernization and industrialization the family assumed an ever-growing role in character education causing the duties of the mother to expand even further. As husbands traveled from the rural countryside into the industrializing urban areas, ". . . a heavy burden [was placed] on mothers, giving them at once new powers in the domestic realm and extraordinary responsibilities for a task that had once been broadly shared by a variety of people with the society" (McClellan, 1999, p. 20). As the family structure changed so did the onus for teaching moral education. Less attention was placed on intellectual development, relying on the schools to instruct reading when children were at a more appropriate age.

Although it did not disappear, educators began to question the adequacy of traditional forms of character education (Hunter, 2000; Salls, 2007). Moreover, the national leadership maintained its belief in the necessity of character education. Theodore 
Roosevelt, President from 1901-1909, commented publicly, "To educate a man in mind and not in morals is to educate a menace to society." (Lickona, 1993b, p.1).

“Between 1900-1940's educators began to respond in two major ways to modernizations and urbanization: they founded the Character Education Movement, which sought to teach specific virtues and traits of good character and also the Progressive Movement, which emphasized a flexible and critical approach to character education without any specific moral tenets" (Salls, 2007, p.10).

The Character Education Movement was influenced by some of the new youth organizations of the time, which included Boy Scouts, 4- H Clubs and Campfire Girls. Both the Character Education Movement and these organizations embraced codes of conduct and used groups to foster cooperation and good behavior. The use of cooperation set apart the Character Education Movement from other nineteen century character education programs. From this point forward, the character education movement developed citizenship grades and motivated students to do the right thing rather than making ethical decisions (Salls, 2007).

By contrast, The Progressive Movement sought to change the methods by which character education was taught, believing moral education should meet the needs of the ever-changing industrial society (McClellan, 1999; Salls, 2007). The Progressive Movement espoused the belief that the moral decisions students faced in the 1920's could not be made through learning a series of fragmented virtues or character traits. It believed everyday situations might yield different ethical choices in which no one virtue 
transcended all others in any single situation (Goodman \& Lesnick, 2001; McClellan, 1999; Salls, 2007).

The progressive era brought with it a spirit of inquiry and a belief that a tolerant and democratic society was what students should work toward. Dewey, the leading theorist on progressive education, stated,

"Moreover, the society of which the child is to be a member is, in the United States, a democratic and progressive society. The child must be educated for leadership, as well as for obedience. He must have power of self-direction and power for directing others, power of administration and ability to assume positions of responsibility" (Salls, 2007, p.15).

Individual behavior was not looked upon with equal importance as what was ethically important for the good of the greater whole (McClellan, 1999; Salls, 2007).

The progressives' view on character education continued through the mid-1940's; the end of the Second World War and the beginning of the Cold War afforded educators an opportunity to promote civic and moral growth (Salls, 2007). These wars were seen as a nationally thematic fight against authoritarian and evil and schools were expected to develop students into defenders of democracy (DeRoche \& Williams, 1998; McClellan, 1999). As the prominence of the United States increased around the world, the academic focus shifted once again. However, informal character education was still taught during the 1940's. The general tone throughout the United States was one of moderation. Students were not only taught specific character traits and virtues, but also the basic premise of ethical flexibility. By doing so, schools effectively eliminated some of the debate about character education that had plagued public schools throughout the 1920's 
and 1930’s (McClellan, 1999; Salls, 2007). “It gradually declined due to increasing pluralism, an emphasis on individualism and a series of Supreme Court decisions finding school systems in violation of the Establishment Clause of the First Amendment" (Vessels \& Boyd, 1996, p.55). Meeting the criteria of the Establishment Clause limited the degree to which morals or values could be imparted to students (Noel, 1997). As a result, many school systems dropped formal character education programs, unable to provide a program that was constitutionally permissible (Noel, 1997; Vessels \& Boyd, 1996).

By the end of the 1950's there had been a subtle neglect of character education programs and they had all but disappeared from public schools (Hayes, 1997; Salls, 2007). According to McClellan and Salls, there were four reasons for the near extinction of character education programs by the end of the 1950's $(1999,2007)$. First was the increased need for scientific, medical and technology minds. The Cold War, space race and the build-up of America's military forces created a demand for more rigorous academic training of students. Students were expected to learn technical and scientific skills as preparation for college (McClellan, 1999; Salls, 2007).

Second, a rising and pervasive anticommunism "hysteria" threatened the way American's had lived for several decades. Students were taught the unquestionable American Way of democracy and independence that was the only good and true way and were warned about those who criticized or questioned the United States. Students were indoctrinated in the belief that if any country or regime threatened the American Way they were seen as “. . . an Enemy of Democracy” (DeRoche \& Williams, 1998; McClellan, 1999, p.74; Salls, 2007). 
Third, an overall belief in the value of personal privacy began to grow toward the end of the 1950's. Some families felt moral education was a religious issue and religion was something that should be taught in the privacy of their homes. It was not the job of schools to interfere with the development of these virtues (McClellan, 1999). Society also saw an increase in the emphasis on individual freedom over personal responsibility (Lickona, 1993b).

Finally, “. . . psychological theories held that children's characters were shaped within the first six years of life" (Salls, 2007, p.12). This reinforced the believe that moral development was of a more private personal issue and should be developed and nurtured within the families, removing it from the responsibility of the schools.

The 1960s and 1970s began with the erosion of formal character education in the schools. Most historians and scholars would agree that these two decades were one of the most tumultuous times in America's history, save the Civil War and Reconstruction epochs. Through the rise of extensive social and anti-government unrest impacted by the unpopular Vietnam Conflict, Civil Rights, urban riots and anti-war demonstrations, it became increasingly clear that Americans would never find the common ground that they desperately sought during the 1890's. McClellan (1999) stated, “Increasingly [schools] sought to preserve a fragile peace by accepting differences and encouraging tolerance" (p.75).

Increasingly, schools were fast becoming the focal point for the growing new civil rights movement for student's personal freedom and choice. As the growing involvement, the federal government delivered and assumed a more substantial role in local schooling. Educators tried to develop academic programs that would create as little controversy and 
offend as few people as possible. Conversely, there were ". . . many occasions local schools became defensive in defiance of what they felt to be the intrusion by the federal government in affairs of local communities" (Salls, 2007, p. 12). People continued to believe that any moral training that occurred was a private matter to be dealt with in the home and not in the schools (McClellan, 1999).

It was also during this time that school personnel began to feel the impact of lawsuits aimed at limiting their scope of influence in students' lives. Two important Supreme Court cases during the 1960's highlighted the decline of moral education in schools. In Engel v. Vitale (1962), the Supreme Court ruled that a public school could not start the day with a nondenominational prayer, which drew a clearer line in the separation between church and state in education (Grigg \& Martin, 1995; McClellan, 1999; Salls, 2007). In the Schempp case of 1963, the Supreme Court ruled against devotional Biblereading in the public school (Grigg \& Martin, 1995; McClellan, 1999; Salls, 2007). Both of these court cases taken together mark the end of religious instruction of any kind within public schools.

School districts and educators viewed these court decisions as a movement away from moral education in public schools. Even though the courts did not prohibit moral instruction in classrooms, teachers began to fear legal repercussions. "Teachers in the 1960's and 1970's saw the trend of judicial decisions as a signal that even purely secular education in the realm of values might violate constitutional standards" (McClellan, 1999, p.78).

The effort by Protestants initially set forth to create a single nonsectarian system of public schooling was ironic. The idea was to create harmony among religious groups. 
". . . champions of the idea of nonsectarianism underestimated the strength of Religious in the society and they failed to find a ground common enough to unite all Protestants. They did much to spread their own faith, but by trying to turn their particular world view a kind of civic religion, they deepened divisions in society, driving embittered dissenters to create their own schools and permanently thwarting the possibility of a single system of public schooling” (McClellan, 1999, p.45).

Equally ironic and ultimately detrimental to the Protestant supporters of public education as the vehicle to spread the connection between morality and religion was the reduction and withdrawal of state aid for nonsectarian schools that did not demonstrate religious neutrality. In other words, the public school leaders were forced to weaken the theological content of moral education in order to continue to receive state aid. What began in the mid-nineteenth as a means of reducing the Catholic school juggernaut and its increasing population and popularity resulted in the secularization of public school across the country by the mid-twentieth century.

Revival of Character Education

The end of the 1960s and early 1970s brought an increased scholarly focus on values education through the research and findings of Lawerence Kohlberg. Kohlberg emphasized values clarification through moral dilemma discussions. Kohlberg's values clarification process encouraged students to choose their values freely, developing their power of reasoning and enabling them to judge which values were most important (Berman, 1995; Black, 1996; Craig, 1978; Elkind, 1998; Greenawalt, 1996; King, 1997; Lickona, 1988; Lickona, 1993b; McDaniel, 1998; Noel, 1997; Pascarella, 1997; Tyree et 
al., 1997). The primary difference in Kohlberg's research and character education programs that had moved through the country since its earliest settlers was the absence of moral absolutes. Students were expected to respond to situations differently based on which stage or level they were at in their moral development. Some in society felt by not teaching specific character traits, schools were in fact allowing students to bend the "moral rules" under the justification that they were not yet fully morally developed individuals (Antis, 1997). Kohlberg in turn feared the generalized acceptance of children's reactions and chose instead to focus on the development of moral decisionmaking by young people. Children and adults would move through the three levels of moral development (pre-conventional, conventional, post-conventional) once they had developed the moral capacity to do so and not before. If educators chose to try to force moral conformity onto those not ready for it, the process would backfire and be a waste of time (Kohlberg, 1981).

With the escalation in the severity and number of incidences of student misbehavior, coupled with the decline in the number of options educational administrators had with discipline issues, the desire to implement character education within schools increased (Benninga \& Wynne, 1998; Berreth \& Berman, 1997; Kann, 1994; Lickona, 1993b; McKay, 1994). One of the first formal character education programs, the Character Education Curriculum, was developed in the mid-1960's at the American Institute of Character Education and spread rapidly throughout the country. (McClellan, 1992). By the late 1980's the curriculum was being taught in 44 states. During the 1980's, the general public, increasingly dismayed at what it viewed as a declining morality in society, began to push for the implementation of formal character 
education in public schools. William Bennett, Secretary of Education during the Reagan Administration, proclaimed it was public education's responsibility to teach virtues such as honesty, kindness, courage, perseverance and loyalty (Antis, 1997; Benninga \& Wynne, 1998; Greenawalt, 1996; Lickona, 1993a). Bennett also believed that education did not need to "re-invent the wheel" by developing numerous formal character education curriculums, but rather should focus on the basic virtues once taught in the early days of schooling (McClellan, 1992). Furthermore, President Clinton also called on the schools to teach character education and values in order to create good citizenship within individual students. He more than tripled the amount of financial support given to character education programs from the Department of Education (Hymowitz, 2003). This perspective was echoed by President Clinton on January $23^{\text {rd }}$ in his State of the Union address when he challenged schools to "teach character education, to teach good values and good citizenship." (Clinton, 1996)

Implementation of Character Education

As different interest groups started to work out their own philosophies and curriculums promoting character education, it was soon apparent that when dealing with something as delicate as the moral development of young people, a "one size fits all" curriculum would not be effective (Lickona, 1996b). In 1995 three national organizations, the Character Counts Coalition, the Character Education Partnership and the Communitarian Network, joined together to promote character education nationwide (Etzioni, 1995; Lickona, 1996a). Out of this coalition, the Character Education Partnership developed the Eleven Basic Principles of Character Education to guide 
educators in teaching character education and the evaluation of its effectiveness (Bulach, 2002; Cooperating School District, 2002; Lickona, 1996a).

The first principle is that schools must determine the primary ethical values that form good character. Lickona (1996a) stated that not only should these values be studied, it is important a school community, "models these values, studies and discusses them; uses them as the basis of human relations in the school... and enforces them by holding all school members accountable to the standards of conduct consistent with the core values" (Lickona, 1996a, p.3). In order to promote and teach the character traits that are universally accepted by all people from different cultures and religions, schools should focus on non-controversial traits such as courage, honesty, respect and trustworthiness (Dobbs, 1997). In addition to these virtues, studies have shown that when schools promote values and behaviors that focus on forgiveness, sympathy and kindness, incidences of violence and bullying decrease (Bulach, 2002).

The second principle is that a character education program must include thinking, feeling and behavioral characteristics. Since describing and explaining different character traits can be interpreted in a variety of ways, schools should also focus on direct and observable behaviors. Behaviors can be reinforced and discussed. Reinforcement of behaviors aids students in determining why it is important to act in certain ways (Bulach, 2002). All members of the school and community should be able to see and recognize the good in others and learn to value it accordingly (Lickona, 1996a). Students must also be able to think about situations, both in their academic studies and in their life encounters and properly assess what their actions should be. Gilness stated, “...unless we help 
students develop critical thinking skills and see connections to other contexts, they will be merely skimming the surface of a story" (Gilness, 2003, p.245).

A third principle is that character education must be pervasive throughout every aspect of the school environment. "Stand alone character education programmes [sic] can be useful first steps or helpful elements of an ongoing effort but must not be considered a substitute for a holistic approach that integrates character development into every aspect of school life" (Lickona, 1996a, p.4). Rather than use the character education curriculum guide to plan short lessons specifically taught like any other subject, character traits should be brought out in all possible ways throughout the day, by the discussions in class and the behavior of the school staff (Bulach, 2002). Character education is much more successful if it is "caught" rather than "taught" (Dobbs, 1997).

Schools must also form a caring and thoughtful community. Students must be able to observe a school's culture actively demonstrating characteristics such as treating each other with kindness, working together for the betterment of the good and listening and working together to meet individual's needs (Lickona, 1996a). Some researchers have gone so far as to indicate that true school reform cannot succeed unless schools “...embed a school culture of character development and create a caring community for learners," (Dobbs, 1997, p. 55). In addition to the development of a culture promoting kindness and cooperation within the school, research also indicates the importance of building a student's sense of community. If students feel valued, important and part of the group, they will sense the school is a caring environment, truly concerned with all aspects of their development (Schaps \& Lewis, 1998). 
Students need to have multiple opportunities to apply the values they have learned to everyday situations and interactions in schools and to be challenged with an academic curriculum that is meaningful and useful to them as individuals (Lickona, 1996a). In addition to working through lessons specifically geared toward moral lessons and encouraging students to discuss and debate them, it has been recognized that it is appropriate to develop and add classes specifically centered on character and morality (Berkowitz, 1998). Not only will learning about values and character traits help students become well-rounded individuals, but a curriculum that is centered on promoting good character has a direct positive relationship to students taking on more academic responsibility, taking challenging classes and expecting high academic standards for themselves (Thomas, 1998). The Character Education Partnership believes students need to move away from needing the extrinsic rewards of doing good and move toward an intrinsic model: one in which students' main concern is more for others rather than for themselves (Lickona, 1996a). By helping to develop the ability to empathize with others and reflect on situations when values break down, schools build students' character development (Berman, 1996). When focusing on someone other than themselves, students also acquire the self-discipline to behave in an ethical manner. Etzioni writes,

Good students, citizens and spouses differ from others in that they have acquired an ability to discern when such feelings swell in their chest and activate countervailing voices that enable them most times to restrain or deflect the anti-social urges, (Etzioni, 1998, p. 35).

A school's primary focus should be to help students develop an internal need to be a good person (Cooperating School District, 2002). 
A fourth principle relates, "the school staff must become a learning and moral community in which all share responsibility for character education and attempt to adhere to the same core values that guide the education of students" (Cooperating School District, 2002, p. 8; Lickona, 1996a, p.6). This basic principle of character education is one of the most important and the underlying basis for this study. Ryan (1995) stated, "Thou shalt be a good example. Deal with it! It's part of the job. It comes with the territory. In fact, you can't avoid being an example, for good or ill; it is probably the most important part of the job" (p.18). In a study looking at the culture of schools trying to implement a character education program, Goldsmith-Conley (1998) stated, "Adults and children are powerfully influenced by how people around them treat each other, how everyday routines are handled and what the environment looks like" (Goldsmith-Conley, 1998, p.50). Students have to see how others should be treated in order to behave accordingly (Bulach, 2002).

Another principle of the Character Education Partnership indicated that there should be at least one person in the school who is the champion of character education (Cooperating School District, 2002). In many cases the responsibility to implement a character education program is placed on the shoulders of one or a few people within the school who do not have the opportunity or authority to ensure it is being implemented effectively. While the input of the staff and community is essential, there must be at least one person in a leadership position to promote and hold people responsible (Bulach, 2002). "Unless the school leadership takes an active role, teachers will pay lip service to the character education program, but will not really support it” (Bulach, 2002, p.4). 
The community and parents should also be invited to become full partners in the character building effort (Lickona, 1996a). Repeatedly the research shows how important it is to involve all stakeholders in this process. "Character education programs are most effective and enduring when the school routinely confers with parents, lets them know what is being taught and involves them in the curriculum" (Brooks \& Kann, 1993, 21). In addition, all those involved in the character development of students should not only help develop the character education program, but should understand what each of the traits means in relation to the program. Different words can mean different things to different people at different times (Bulach, 2002).

Finally, the students, staff, parents and community should assess and evaluate the character of the school and the people in it in order to determine if the students and staff exhibit good character. "Implementation of a character education program must include a pre-assessment of goals, consultation during the program and a post-program evaluation of the results" (Brooks \& Kann, 1993, 21). Asking individual schools or school districts to develop action plans outlining the course of character education implementation can help guide the direction the stakeholders want the curriculum to take (Huffman, 1993). Future planning can then be guided by the results of the ongoing evaluation (Lickona, 1996a).

All of these qualities have been deemed essential for a character education program to be successful (Berkowitz, 2000). When looking at them from an objective standpoint, it is clear most of them are related to some degree to the culture of the school. For example, in their consideration of school culture, Deal and Peterson (1999) discussed 
the importance of community, a unified vision and mission statement, a staff committed to growing and learning together including positive role models.

\section{Character Education and School Culture}

Deal and Peterson (1999) have stated the importance of culture on the staff and community of the school. "Culture amplifies the energy, motivation and vitality of a school staff, its students and community.” (p.8). Similarly, Goldsmith-Conley (1998) stated, "What really counts in education is the kind of school communities in which social interchanges occur and the reflection of participants about their community [occurs]"' (p.50).

Researchers have agreed on the importance of schools and staff having a focused vision and purpose to character education. Berkowitz (2000) noted that, "We believe that effective character education requires an intentional, proactive and comprehensive approach that is a part of all phases of school life. Character education should be viewed as an integral part of the school's environment; not a completely separate program" (p.2). Likewise, a school's culture should encourage learning and progress while building "a community spirit valuing purposeful change" (Deal \& Peterson, 1999, p.8).

The topic of culture was pervasive when Deal and Peterson (1999) discussed the importance of a staff that works and learns together. Deal and Peterson (1999) stated,

Culture fosters school effectiveness and productivity. Teachers can succeed in a culture focused on productivity (rather than on maintenance and ease of work), performance (hard work, dedication and perseverance) and improvement (continuous fine-tuning and refinement of teaching). 
Such a culture helps teachers overcome the uncertainty of their work by providing focus and collegiality (p.7).

In addition, schools that build a culture of collegiality and collaboration provide for an atmosphere conducive to new and innovative professional development (1999). When considering specifically the implementation of a character education program, the same idea holds true. Training in the design and implementation of a character education program should be ongoing and must include an element of well-thought-out reflection and discussion as well as ample planning time (Cooperating School District, 1999). When discussing character education implementation, Lickona (1996a) stated, "all school staff-teachers, administrators, counselors, coaches, secretaries, cafeteria workers, playground aides, bus drivers — must be involved in learning about, discussing and taking ownership of the character education effort" (p.6).

Throughout many of the investigations on character education, researchers have agreed on the importance of having positive adult role models in the school. McKay (1994) postulated that, "society, parents and educators must look to themselves. Character education programs, or any other values education programs, cannot teach children values in the absence of demonstrations of these values on the part of educators and others in children's lives" (p.46). Schools having focused values and positive adult behavior are more likely to have quality instruction, high student achievement and a continuous need to improve (Deal \& Peterson, 1999). Heft (1995) further summarized this postulate by stating,

My final point, then, about character education, is that teachers will need to become more comfortable with thinking of themselves as models, or at 
least as mentors, as individuals who are willing to teach students not only basic values, but also ways to act, ways to learn the craft of what it means to be a human being who is able to see others as their brothers and sisters (p.400).

While it is clear in the research that character education and the culture of a school are invariably linked, the questions remain: What is the role of school culture in the implementation of a character education program? Are there factors of culture so difficult to overcome that a character education program could never be fully implemented?

Summary

Character education has been prevalent in society since the ancient Greeks (Bennett, 1988; Benninga \& Minkler, 1997; Benninga \& Wynne, 1998; Close, 1997; Heft, 1995; Lickona, 1998a; Sockett \& Alston, 1989; Wynne, 1988). In America, the early settlers taught values and virtues through home and religious instruction (McClellan, 1992). This continued until formal schools were developed that took over some of the moral instruction of young people (Greenawalt, 1996). Although character education moved back and forth between religious and secular instruction for the next three hundred years, it was not until landmark court cases in the 1960s separated religion from the public schools (Grigg \& Martin, 1995) and for the time being, lessened the use of character education in school. Character education came back into the public eye during the 1980s when society saw what it believed to be the deterioration of the moral fiber of young people (Antis, 1997; Benninga \& Wynne, 1998; Greenawalt, 1996; Lickona, 1993a). 
Although many schools have embraced character education and others have been forced to adopt it, there is no "one size fits all" program that schools can implement (Lickona, 1996b). Researchers have agreed there are other factors besides a written curriculum that are important for effective character education to take place. The Character Education Partnership has proposed the "Eleven Principles of Effective Character Education" (Lickona, 1996a). These principles address the importance of having agreed upon core ethical values in the program that impact the thinking, feeling and behavior of students (Bulach, 2002; Dobbs, 1997; Lickona, 1996a). Character education should envelop all aspects of school life (Bulach, 2002; Dobbs, 1997; Lickona, 1996a) and the school must be a caring community (Dobbs, 1997; Lickona, 1996a;

Schaps \& Lewis, 1998). Students need opportunities to discuss and reflect upon a variety of moral issues and have a strong curriculum to back it up (Berkowitz, 1998; Lickona, 1996a; Thomas, n.d.). Students' intrinsic motivation should be developed to lessen the need for extrinsic rewards (Berman, 1996; Etzioni, 1998; Lickona, 1996a) and the entire school community should strive to promote the same values as taught in the curriculum (Bulach, 2002; Cooperating School District, 2002; Goldsmith-Conley, 1998; Lickona, 1996a; Ryan, 1995). Character education requires moral leadership within the school (Bulach, 2002; Cooperating School District, 2002) and the school must reach out to the community to enlist the help of parents and patrons as partners in the character building effort (Brooks \& Kann, 1993; Bulach, 2002; Lickona, 1996a). Finally, character education programs should be evaluated regularly to determine whether the program is meeting its objectives (Brooks \& Kann, 1993; Bulach, 2002; Lickona, 1996a). Having these principles in place will help in making a character education effort successful. 
Schools with positive cultures have staffs with a shared sense of vision and a unity of purpose (Gruenert, 1998). All of the adults in the school act and behave in appropriate, ethical and collaborative ways (McKay, 1994). Teachers and students are encouraged to adopt leadership roles and take risks in their instruction and learning (Cooperating School District, 2002). Schools will also reinforce the norms that have been established within the staff and community (Schein, 1992). It is difficult to start a character education program in an organization that does not have the positive culture conducive to its establishment (Dobbs, 1997). Individuals within the school will have to integrate the philosophy behind the character education program into the already established culture (Lickona, 1996a).

The goals of the program should be verbalized openly and embraced by every member of the school community (Brooks \& Kann, 1993). Positive Behavioral Interventions and Support or PBIS a tactical approach to sustaining a school-wide character education program. Improving student academic and behavior outcomes is about ensuring all students have access to the most effective and accurately implemented instructional and behavioral practices and interventions possible. This data provides school leaders the decision-making ability to respond to school-wide concerns in a timely and efficient manner. PBIS data streamlines the decision-making, making the ability to affect school culture more fluid and powerful. How the members of an organization respond to the external forces that are inevitably involved when a character education program is being developed depends largely on the culture of the organization itself. 


\section{CHAPTER THREE}

Methodology

In this section, the outline of research design and the method of implementation are discussed. A school's culture and character education efforts must be closely aligned. This statement is reinforced by McGill (2001) which states, schools must first have internalized the beliefs and values they wish to impart to the students. Numerous studies have been conducted on character education and school culture. A chi square test of association was used to determine if any direct relationship exists between the implementation of the initial embedded character education program and the recognition as a National School of Character. A chi square test of association is one of the most commonly used statistical approaches to repeated measures designs.

Purpose of the Study

More and more schools are deciding to implement a character education program, or they are being forced to do so (McClellan, 1992; Milson, 2000). Given that a character education curriculum inherently deals with the formulation and development of character traits and values of students, it is essential that the school itself embrace the values and traits it is trying to teach students (McGill, 2001). Much of the research indicates that a school must have a positive culture in order to effectively implement a character education program (Lasley, 1997; McGill, 2001). Positive adult role models, a collaborative work environment and collegiality among the students, staff and parents of the school's students can promote a positive culture and the necessary support structures needed to implement character education (Deal \& Peterson, 1999; Lickona, 1996). 
An important question for parents, educators and policy makers today involves the long-term impact an embedded character education program will have on the moral and ethical development of students. Every school district across the United States of America is faced with continually increasing challenges of creating students that are wellrounded human beings capable of making moral, ethical decisions in an ever-increasingly immoral and unethical world (Lickona, 1996; Riley, 2001). This issue of moral and ethical development, in particular to what would become the United States, can be found in the writings and beliefs of the Pilgrims, Puritans and Quakers. President Theodore Roosevelt summarized the issue of moral responsibility placed on public schools by his statement: "To educate a man in mind and not in morals is to educate a menace to society" (Lickona, 1996a, p.3).

In order to cope with this educational and societal need, formal character education programs are being quickly reinstituted within school districts across the country (Milson, 2000). Moreover, research suggests that along with the decline of formal character education in schools during the 1950s and 60s came an increase in the focus on the individual rather than on the greater good (DeRoche \& Williams, 1998; McClellan, 1997). Furthermore, stemming from an individualized focus resulted in a rise in anti-social behavior, leading to such things as increased youth violence, dishonesty, disrespect, bigotry, self-centeredness and a decline in overall work ethic (Lickona, 1996a). Although there have been many studies conducted on character education, the relationship between student-to-student and student-to-teacher is what will be examined in this dissertation. The purpose of this program evaluation is to realize how relationships between student-to-student and student-to-teacher, which includes bullying, disrespect 
and aggression have been affected from the inception of a school-wide character education program to national character education recognition.

This study reviews student discipline data collected over a period of three years starting in August 2007-08, 2008-09 and ending May2009 to examine how an embedded character education program affected the relationships between student-to-student and student-to-teacher from the implementation of the program to receiving a National Character of Schools award in 2009.

\section{Research Questions}

Research questions that arose from the problem and purpose of this program evaluation examine relationships between student-to-student and student-to-teacher during the implementation of a nationally recognized character education program. Data was collected and analyzed by discipline criteria as students entered the character education program, during their sixth through their seventh and upon exiting the program during the eight grade year. The primary research questions examined in this study are as follows:

1. Has the character education program limited student-to-student and student-toteacher fighting and bullying from inception of the character education program to national recognition as measured by discipline referral data?

2. Has the character education program limited student-to-student and student-toteacher disrespect from the inception of the character education program to national recognition as measured by discipline referral data? 
3. Has the character education program limited student-to-student and student-toteacher insubordination from the inception of the program to national recognition as measure by student discipline referral data?

H1) There is no difference in the relationship as measured by student discipline referral data.

H2) There is no difference in the relationship as measured by student discipline referral data.

H3) There is no difference in the relationship as measured by student discipline referral data.

Population

The study's population consisted of approximately 110 students over a period of three years all from the same school. The data were collected during each cohort/grade level first during the student's sixth grade year, again in seventh grade and upon completion of eighth grade while attending the junior high school. Specifically, the junior high school is a $7^{\text {th }}$ and $8^{\text {th }}$ grade facility that was built in 1934 , originally as a high school. Dissecting the demographics further, $74 \%$ of the population is identified as Caucasian, within that category, 35\% are Bosnian. Moreover, $11.5 \%$ are identified as African American. Asian students account for $12 \%$ and $3 \%$ identify themselves as Latino/Latina. Furthermore, $64 \%$ of the students are eligible for free or reduced-price meals and an average of $95 \%$ of the students are in attendance on a daily basis (DESE, 2011). Of the overall population, females represent $46 \%$ and the males account for $54 \%$. 


\section{Instrumentation}

The instrument for collecting the discipline referral data during the 2007 - 2009 school years was a web-based technology program. The program was designed to filter and categorize all discipline referral data entered by student offense and date. The data collected were defined into student-to-student and student-to-teacher categories. Data was entered by an administrator or a designee based on written office discipline referrals. These office discipline referrals are written by teachers or other staff pertaining to a discipline issue concerning a student's actions and behavior. Inaccurate data entry could have an effect of the number of correctly assigned student discipline referral data; however, this inaccuracy would be insignificant.

\section{Data Collection}

The school discipline data is collected on a monthly basis and analyzed. Monthly data is then combined to provide an overall picture of the school year's discipline results. Three cohorts from 2007, 2008 and 2009 are the subjects of this analysis. The pre data was accumulated at the end of the cohorts' sixth grade year. The post data, on the same cohort, was collected at the end of the students' eighth grade year. The collection of data was focused in three areas or criteria: aggression, which includes fighting and bullying; disrespect and insubordination. The data collected were defined into student-to-student and student-to-teacher categories. Data was entered by an administrator or a designee based on written office discipline referrals. These office discipline referrals are written by teachers or other staff pertaining to a discipline issue concerning a student's actions and behavior. 
Data Analysis

The Pearson Chi square test of association was used to determine whether or not two variables that are nominal or categorical are associated with each other. The test offered a way to determine whether a set of observed $(\mathrm{O})$ frequencies deviates from a set of expected (E) frequencies. The Pearson chi-square test which is also known as the chisquare goodness-of-fit was used.

$$
\chi_{\mathrm{c}}^{2}=\sum \frac{\left(\mathrm{O}_{\mathrm{i}}-\mathrm{E}_{\mathrm{i}}\right)^{2}}{\mathrm{E}_{\mathrm{i}}}
$$

The chi-square test will be used to show any statistical significance between the number of discipline referral data at the implementation of the character education program to the time when the national recognition was received. The chi-square test statistic is designed to test the null hypothesis that there is no association or relationship to the character education program and discipline referral data.

Summary

There is vast evidence to indicate in the review of the literature that there has been an increase in the amount of character education taught in public schools since the 1980s (Berkowitz, 1998; Lickona, 1996a).

A Chi-square test of association is one of the most commonly used statistical approaches to repeated measures designs. There have been many studies conducted on school culture, character education and even possible correlation between school culture and character education. A school's culture and character education efforts must be closely aligned. This statement is reinforced by McGill (2001) which states, schools must first have internalized the beliefs and values they wish to impart to the students. 
The next section contains the findings of the qualitative data and an analysis of all research questions. The final section is a summary of the findings, conclusions, implications and recommendations for further research. 


\section{CHAPTER FOUR}

\section{Presentation and Analysis of Data}

The intent of this study was to examine relationship as defined as student-tostudent and student-to-teacher. The purpose of this program evaluation is to realize how relationships between student-to-student and student-to-teacher, which include bullying, disrespect and aggression, have been affected from the inception of a school-wide character education program to a national character education recognition.

The Pearson's Chi-squared distribution was calculated to determine the strength of the relationships between the inception of the character education program to national recognition as measured by discipline referral data.

The data were analyzed in an effort to answer the following research questions:

1. Has the character education program limited student-to-student and student-to-teacher fighting and bullying from inception of the character education program to national recognition as measured by discipline referral data?

Based on the data, it can be concluded that there was no significant difference between student-to-student and student-to-teacher aggression from the inception of the character education program to national recognition.

2. Has the character education program limited student-to-student and student-to-teacher disrespect from the inception of the character education program to national recognition as measured by discipline referral data? 
Based on the data, we can conclude that there was no significant difference between student-to-student and student-to-teacher disrespect from the inception of the character education program to national recognition.

3. Has the character education program limited student-to-student and student-to-teacher insubordination from the inception of the program to national recognition as measure by discipline referral data?

Based on the data, we can conclude that there was no significant difference between student-to-student and student-to-teacher insubordination from the inception of the character education program to national recognition.

\section{Data Collection Instruments}

The data was collected using Tyler Student Information System- K12. This software program is designed to collect, correlate and prepare student-related data for review and documentation. Specific information from a referral or incident is entered into the software program by keyboard. All information is kept confidential and requires administrative permission to access the software program.

Chi-square is a statistical test commonly used to compare observed data with data we would expect to obtain according to a specific hypothesis. The chi-square test is always testing what is called the null hypothesis, which states that there is no significant difference between the expected and observed result. This test is the best fit when working with numbers and not percentages. This program study reviewed the number of referrals over a three year period, making the Chi-square statistical test the best fit. 
Data Analysis

The Junior High School is one of the most diverse schools in the State of Missouri according to the Missouri Department of Elementary and Secondary Education (2012). The City of St. Louis has become a home for thousands of Bosnian refugee families after the breakup of the former Yugoslavia and the Bosnian War beginning in 1992. Moreover, $35 \%$ of the $73.9 \%$ that identify themselves as white/Caucasian are ethnically Bosnian. The remaining student populations include 11.5\% black/African American, 11.9\% Asian and 2.7\% Latino/Latina (DESE, 2012). This diversity has provided authentic character education opportunities for the school to create caring communities, provide students with opportunities for moral action and for the school staff to model as an ethical learning community (Character Education Partnership, 2010).

Within the Junior High School, there is a 19 to 1 student/teacher ratio. Based on research by Marvin Berkowitz and Melinda Bier (2004), a smaller student to teacher ratio and ultimately a smaller number of students in a classroom provide for strong authentic opportunities to build community. The program study is comprised of three cohort student populations 2007, 2008 and 2009. 
Table 1

Demographic Population of Junior High School

$\underline{\text { Characteristics }}$

Percentage $\%$

Caucasian

White $\quad 73.9$ (35\% are Bosnian)

Black $\quad 11.5$

Asian $\quad 11.9$

Latino/Latina $\quad 2.7$

Free/Reduced Lunch $\quad 64.4$

Average Attendance $\quad 95.8$

Gender

Females $\quad 46$

Males 54

Student/Teacher Ratio 19 to 1

A Pearson's Chi-square test was conducted to determine if there was an association among the four test variables; fighting and bullying, disrespect and insubordination (Table 2) for a cohort of students during their sixth grade year starting the award winning character education program, National School of Character. There was no significant association between these reported behaviors, indicating the variables are independent of each other. 
Table 2

Grade 6

\begin{tabular}{lllll}
\hline & Bullying & Disrespect & Insubordination & Fighting \\
\hline Bullying & 0 & .223 & .083 & .223 \\
Disrespect & .223 & 0 & .223 & .199 \\
Insubordination & .083 & .223 & 0 & .223 \\
Fighting & .223 & .199 & .223 & 0 \\
\hline
\end{tabular}
$\mathrm{p}>.05$

A Pearson's Chi-square test was conducted to determine if there was an association between fighting and bullying, disrespect and insubordination (Table 3) for a cohort of students during their seventh grade year starting the award winning character education program, National School of Character. There was no significant association between these reported behaviors, indicating the variables are independent of each other.

Table 3

Grade 7

\begin{tabular}{lllll}
\hline & Bullying & Disrespect & Insubordination & Fighting \\
\hline Bullying & 0 & .223 & .223 & .223 \\
Disrespect & .223 & 0 & .199 & .199 \\
Insubordination & .223 & .199 & 0 & .199 \\
Fighting & .223 & .199 & .199 & 0 \\
\hline p>.05 & & & &
\end{tabular}

A Pearson's Chi-square test was conducted to determine if there was an association between fighting and bullying, disrespect and insubordination (Table 4) for a cohort of students starting the award winning character education program, National School of 
Character. There was no significant association between these reported behaviors, indicating the variables are independent of each other.

Table 4

Grade 8

\begin{tabular}{lllll}
\hline & Bullying & Disrespect & Insubordination & Fighting \\
\hline Bullying & 0 & 157 & .157 & .157 \\
Disrespect & .157 & 0 & .157 & .157 \\
Insubordination & .157 & .157 & 0 & .157 \\
Fighting & .157 & .157 & .157 & 0 \\
\hline
\end{tabular}

p>.05

The next set of data tables indicate the total number of referrals during the three year period involving the cohort of students starting in sixth grade and continuing through eighth grade. These data tables display the number of referrals collected over the three year period involving fighting and bullying, disrespect and insubordination.

Total number of fighting and bullying referrals was calculated during each school year. The number of referrals (Table 5), over the three year period, show there was no significant patterns or associations, indicating the variables are independent of each other.

Table 5

Fighting and Bullying Referrals

\begin{tabular}{ll}
\hline 2006-2007 & $\mathrm{n}$ \\
\hline Grade 6 & 3 \\
Grade 7 & 26 \\
Grade 8 & 9 \\
\hline
\end{tabular}

$\mathrm{n}=$ number of referrals 
Total number of disrespectful referrals was calculated during each school year. The number of disrespectful referrals (Table 6), over the three year period, show there was no significant patterns or associations, indicating the variables are independent of each other.

Table 6

Disrespectful Referrals

2007-2008

$\mathrm{n}$

Grade 6

Grade 7

Grade 8 65

$\mathrm{n}=$ number of referrals

Total number of insubordination referrals was calculated during each school year. The number of insubordination referrals (Table 7), over the three year period, show there was no significant patterns or associations, indicating the variables are independent of each other.

Table 7

Insubordination Referrals

2008-2009

Grade 6 $\mathrm{n}$

Grade 7 7

Grade 8 10

$\mathrm{n}=$ number of referrals

Findings

Research question 1. Has the character education program limited student-tostudent and student-to-teacher fighting and bullying from inception of the character 
education program to national recognition as measured by discipline referral data? A Pearson's Chi-square test was conducted to determine if there was an association between fighting and bullying, disrespect and insubordination for a cohort of students starting the award winning character education program, National School of Character. There was no significant association between these disciplines reported behaviors, indicating the variables are independent of each other.

Research question 2. Has the character education program limited student-tostudent and student-to-teacher disrespect from inception of the character education program to national recognition as measured by discipline referral data? A Pearson's Chisquare test was conducted to determine if there was an association between aggression (fighting and bullying), disrespect and insubordination for a cohort of students starting the award winning character education program, National School of Character. There was no significant association between these disciplines reported behaviors, indicating the variables are independent of each other.

Research question 3. Has the character education program limited student-tostudent and student-to-teacher insubordination from inception of the character education program to national recognition as measured by discipline referral data? A Pearson's Chisquare test was conducted to determine if there was an association between fighting and bullying, disrespect and insubordination for a cohort of students starting the award winning character education program, National School of Character. There was no significant association between these disciplines reported behaviors, indicating the variables are independent of each other.

Summary 
The purpose of this investigation was to provide a program evaluation of a character education initiative from the implementation to the national award recognition over a three year period, beginning 2007 through 2009. Although this junior high school was recognized as a Nation School of Character in 2009, the data shows no significant relationship in limiting student-to-student or student-to-teacher fighting and bullying, disrespect or insubordination referrals during this three year period. There was no significant association between discipline reported behaviors, indicating the variables are independent of each other. In the final section, the researcher uses this data analysis to discuss the findings and determine the implications for further research. 


\section{CHAPTER FIVE}

Summary and Recommendations

This program study reviews student discipline data collected over a period of three years starting in August 2007-08, 2008-09 and ending May 2009 to examine how an embedded character education program affected the relationships between student-tostudent and student-to-teacher from the implementation of the program to receiving a National Character of Schools award in 2009. This program evaluation follows a cohort of students starting in 2007 during their $6^{\text {th }}$ grade year and concludes in 2009 at the end of their $8^{\text {th }}$ grade year. The relationships between student-to-student and student-to-teacher, which includes aggression, disrespect and insubordination have been affected from the inception of a school-wide character education program to a national character education recognition were examined in this study. Provided in this chapter is a summary of the overall project. A thorough discussion of the findings is provided as well as the study's limitations, implications for practice and recommendations for further research.

Although there have been many studies conducted on character education (Goldsmith-Conley, 1998; Lasley, 1997; McGill, 2001), as well as studies on social 
interactions in middle/junior high schools, the relationship for the purpose of this study is defined as student-to-student and student-to-teacher, has on the implementation of character education has yet to be fully examined. The purpose of this program evaluation is to realize how relationships between student-to-student and student-to-teacher, which include fighting and bullying, disrespect and insubordination, have been affected from the inception of a school-wide character education program to national character education recognition. As a point of interest for the reader: $73.9 \%$ of the population is identified as white/Caucasian, within that category, 35\% are Bosnian. $11.5 \%$ are black/African American. 11.9\% students are identified as Asian, mostly from Vietnam and the remaining $2.7 \%$ of the students identify themselves as Latino/Latina. Furthermore, $64.4 \%$ of the students are eligible for free or reduced-price meals and an average of $95.8 \%$ of the students are in attendance and over 20 different languages are spoken by the caregivers and guardians (DESE, 2013). Taking the whole student population into account, females represent $46 \%$ and the males make up 54\%. The staff, including administrator and counselor, is predominately white/Caucasian at over $90 \%$. There is a 19 to 1 student/teacher ratio and a 261 to 1 student/administrator ratio.

Schools have been encouraged over the past three decades to provide some kind of character education training to students (DeRoche \& Williams, 1998). Lickona, in 1996, wrote that character education is most beneficial when implemented in a thoughtful, comprehensive, and direct manner. Effective implementation is reported to require adult role models, student leadership, community participation, and defined traits within an integrated curriculum (McKay, 2002). Research also indicates that implementing a character education program can have positive results throughout an 
entire school system (McGill, 2001). Researchers agree a positive school culture is necessary for effective implementation of character education (Goldsmith-Conley, 1998; Lasley, 1997; McGill, 2001).

The literature review revealed a long and extensive history or moral and character education development dating back to the early 1600s and 1700s involving the homeschool teachings of the Pilgrims and Puritans. As the popularity of a free public education began to grow during the 1800 s, schools started to take on more of this responsibility up to and including the mid-1900s. However, secular and non-secular differences pushed moral education from the classrooms almost completely. It was not until the 1970s that a call from government and civic leaders for more intentional character education developed. This began the modern implementation of the character education programs found in most schools around the country.

The research questions guiding this study were as follows:

1. Has the character education program limited student-to-student and student-to-teacher fighting and bullying from inception of the character education program to national recognition as measured by discipline referral data?

2. Has the character education program limited student-to-student and student-to-teacher disrespect from the inception of the character education program to national recognition as measured by discipline referral data?

3. Has the character education program limited student-to-student and student-to-teacher insubordination from the inception of the program to national recognition as measure by discipline referral data? 
These research questions were developed as a result of an extensive literature review on the history and the factors involved in the effective implementation of a character education program. Common infractions or discipline referrals found in a student handbook include insubordination, disrespect, bullying and fighting among others. In the scope of character education, the effectiveness of the program would be determined by the limitation of the before mentioned infractions.

Findings

The quantitative data analysis confirmed that there were no significant differences among the relationships between student-to-student and student-to-teacher, which include fighting and bullying, disrespect and insubordination affected from the inception of a school-wide character education program to national character education recognition. The Pearson Chi-square test established the independence of behaviors among the four behaviors, fighting and bullying, disrespect and insubordination. The descriptive data was also valid and supports the trends in the data involving the four behaviors.

\section{Conclusions}

Results of this study showed that no significant limitations were established between student-to-student and student-to-teacher fighting and bullying, disrespect and insubordination from the inception of the character education program to its national recognition. No difference was found in the relationship as measured by student discipline referral data. The hypothesis was correct; there is no difference in the relationship as measure by discipline referral data.

Limitations and Design Control 
There were several limitations to this study; however the researcher took every measure to minimize the effects of these limitations on the study. The researcher received input and guidance from colleagues and advisors, all experienced researchers, throughout the course of this study. The researcher recognized the following limitations:

This study was limited by the validity and reliability of the instruments used.

1) This study was limited by the validity and reliability of the instruments used.

2) The possibility of human error when entering the data into the software program.

3) This study was limited to three years of data.

4) Limited to one cohort of students.

5) This study was limited by the administration and teacher's level of conviction and comprehension of professional expectations and procedures.

Any concerns about possible repercussions were eliminated by the complete anonymity of all respondents and examining all surveys in aggregate rather than individually. Results were presented in an aggregate format to further reduce any possibility of participant identification or retribution.

Implications for Practice

The findings of this study indicate the lack of limits or increases in discipline referrals from the inception of the character education program to the national recognition. By following a single student cohort over a three year period, no significant reduction in identified referrals was observed. Recommendations for Future Research 
The Character Education Partnership believes a school's culture must change for character education to be effectively implemented (Ries, 1999). This can consist of many factors, such as having positive adult role models; a collaborative work atmosphere; and collegiality among the students, staff and parents of the school (Deal \& Peterson, 1999; Lickona, 1996). Character education programs can have positive effects on school-age children. In order for a character education program to be fully implemented and effective, schools must build a positive, focused and integrated curriculum.

An integrated curriculum embeds character education traits into everyday lessons and objectives making the student's experience and learning more authentic and grounded in reality. This integrated program is cross-curricular, making all adults responsible for teaching character education. Adult role modeling is also an essential component of an effect character education program. Students learn from watching and interacting with others, especially adult educators.

Adult role modeling demonstrates the traits students should learn and buttresses the objectives of a formal character education curriculum.

Embedding character education and adult role modeling are both skills that need to come from sustainable professional development. This type of professional development would provide for clear expectations for both adults and students, including policy and procedures, and handling all referrals to the office for discipline.

This program study indicates there is no significant limitation in the relationship involving discipline referrals from the inception of the character education to the national recognition. This leads to a conclusion that the national recognition maybe less concerned 
about reduction in discipline referrals, and may put more weight on practice, procedures and policy. 


\section{Bibliography}

Antis, J.E. (1997). An evaluation of the effect of a character education program on the ethical understanding, ethical sensibility, and ethical behavior of elementary children (Doctoral dissertation, Duquesne University, 1997). Dissertation Abstracts International, 58(01), 0748A.

Barth, R. (1990). A personal vision of a good school. Phi Delta Kappan, 71(7), 512-516.

Bennett, W.J. (1988). Moral literacy and the formation of character. NASSP Bulletin, 72 (512), 29-34.

Benninga, J.S. \& Minkler, J. (1997). Clearinghouse established for character education. Social Studies Review, 37(1), 77-78.

Benninga, J.S. \& Wynne, E.A. (1998). Keeping in character: A time-tested solution. Phi Delta Kappan, 79(6), 439-445, 448.

Berkowitz, M.W. (1998). The education of the complete moral person. Retrieved May 21, 2002, from http://tigger.uic.edu/ Inucci/MoralEd/articiles/berkowitzed.html.

Berkowitz, M.W. (2000). A primer for evaluating a character education initiative. Marquette University, Character Education Partnership.

Berkowitz, M.W. \& Bier, M.C. (2004). Research-based character education. Annals of the American Academy of Political and Social Science. 591.

Berkowitz, M.W. \& Fekula, M.J. (1999). Educating for character. About Campus, Nov./Dec., 17-22.

Berman, S.H. (1995). Where focus on the family falls short on character development: Four reactions from school leaders. The School Administrator, 52(8), 24-25. Berreth, D. \& Berman, S. (1997). The moral dimensions of schools. Educational 
Leadership, 54 (8), 24-27.

Black, S. (1996). The character conundrum. The American School Board Journal, 183 (12), 29-31.

Brooks, D. \& Kann, M.E. (1993). What makes character education programs work? Educational Leadership, 51(3), 19-21.

Bulach, C.R. (2002). Implementing a character education curriculum and assessing its impact on student behavior. Clearing House, 76(2), 79-83.

Character Education Partnership. (2010). A framework for school success: 11 principles of effective character education. United Stated of America.

Clinton, W.J. (1996). State of the union. Speech presented at joint secession of congress, Washington, D.C.

Close, Frederick. (1997). The fundamentals of character education. Social Studies Review, 37(1), 93-94.

Cooperating School District. (1999). Evaluation resource guide: Tools and strategies for evaluation a character education program. St. Louis, MO: Cooperating School District.

Cooperating School District. (2002). Evaluation resource guide: Tools and strategies for evaluation a character education program. St. Louis, MO: Cooperating School District.

Craig, R. (1978). Some thoughts on moral growth. Journal of Thought, 13(1), 21-27.

Deal, T.E. \& Peterson, K.D. (1999). Shaping school culture: The heart of leadership. San Francisco: Jossey-bass. 
Department of Elementary and Secondary Education. (2012). Retrieved from http://dese.mo.gov/

DeRoche, E. F. \& Williams, M. M. (1998). Educating hearts and minds: A comprehensive character education framework._Thousand Oaks, CA: Corwin Press, Inc.

Dobbs, D. (1997). Character education as a key component of school reform. Social Studies Review, 37(1), 54-55.

Elkind, D. (1998). Character education: An ineffective luxury? Child Care Information Exchange (124), 6,8-9.

Etzioni, A. (1995). When parents default, schools should teach character. Brown University Child and Adolescent Behavior Letter, 11(1), 1-3.

Etzioni, A. (1998). On a character education inventory. The School Administrator, 55(5), $35-36$.

Freado, R.G. (1997). Implementing a comprehensive character education program (University of Pittsburgh, 1997). Dissertation Abstracts International, xx(xx), XXXxx.

Fullan, M.G. \& Hargreaves, A. (1996). What's worth fighting for in your school? Buckingham: Open University Press.

Gilness, J. (2003). How to integrate character education into the curriculum. Phi Delta Kappan, 85(3), 243-245.

Goldsmith-Conley, E. (1998). School culture before character education: A model for change. Action in Teacher Education, 20(4), 48-58.

Goodman, J.F. \& Lesnick, H. (2001). The moral stake in education. New York: 
Longman.

Greenawalt, C.E. (1996). Character education in America. (Report No. UD-031-139). Harrisburg, PA: Commonwealth Foundation for Public Policy Alternatives. (ERIC Document Reproduction Service No. ED 398 327)

Grigg, P.G. \& Martin, W.C. (1995). Moral education: Where have we been? Where are we going? (Report No. PS-023-546). Pensacola, FL: Office of Educational Research and Improvement. (ERIC Document Reproduction Service No. ED 385 396)

Gruenert, S. (1998). Development of a school culture survey (University of Missouri Columbia, 1998). Dissertation Abstracts International, 59(08), 2794A.

Hayes, B. (1997). Character education and civic participation programs. Social Studies Review, 36(2), 51-53.

Heft, J.L. (1995). Can character be taught? Journal for a Just and Caring Education, 1(4), 389-402.

Hunter, J.D. (2000). The death of character: Moral education in an age without good or evil. New York: Basic.

Huffman, H.A. (1993). Character education without turmoil. Educational Leadership, 51(3), 24-26.

Hymowitz, K. S. (2003). The return of character education? Public Interest, 151, $104-$ 109.

Kann, M. (1994). Discipline, character and education. Teaching education, 6(1), 71-75. King, P. M. (1997). Character and civic education: What does it take? Educational Record 87-93. 
Kohlberg, L. (1981). The philosophy of moral development: Moral stages and the idea of justice. New York: Harper \& Row.

Lasley, T. J. (1997). The missing ingredient in character education. Phi Delta Kappan, $78(8), 654-655$.

Lickona, T. (1993a). Is character education a responsibility of the public schools? Yes. Momentum, 24(4), 48-54.

Lickona, T. (1993b). The return of character education. Educational Leadership, 51(3), 6-13.

Lickona, T. (1996a). Eleven principles of effective character education. Journal of Moral Education, 25(1), 93-100.

Lickona, T. (1996b). Teaching respect and responsibility. Journal of Emotional and Behavioral Problems, 5(3), 143-151.

Lickona, T. (1998). Character education: Seven crucial issues. Action in Teacher Education, 20(4), 77-84.

McClellan, B. E. (1992). Schools and the shaping of character: Moral education in America, 1607-present. (Report No. SO-022-845). Washington, D.C.: Office of Educational Research and Improvement. (ERIC Document Reproduction Service No. ED 352 310)

McClellan, E. (1999). Moral education in America: Schools and the shaping of character from colonial times to the present. New York: Teachers College Press.

McDaniel, A. (1998). Character education: Developing effective programs. Journal of Extension 36(2). 
McGill, J. (2001). Raising reasonable people: rectifying mission and culture in schools. Independent School, 60(4), 78-84.

McKay, L. (2002). Character education with a plus. Education Digest, 60(4), 45-50.

McKnight, D. (2003). Schooling, the puritan imperative, and the molding of an American national identity: Education's "errand into the wilderness.” Mahwah, New Jersey: Lawrence Erlbaum Associates.

Milson, A.J. (2000). Creating a curriculum for character development: A case study. The Clearing House, 74(2), 89-93.

Noel, M. (1997). Morality in education. (Report No. SO-029-489). East Lansing, MI: Office of Educational Research and Improvement. (ERIC Document Reproduction Service No. ED 429 878)

Pascarella, E. (1997). College's influence on principled moral reasoning. Educational Record, 78(3-4), 47-55.

Peterson, R. \& Skiba, R. (2001). Creating school climates that prevent school violence. Clearing House, 74(3), 155-163.

Ries, E. (1999). A question of character. Techniques: Making education and career connections, 74(5), 26-29.

Riley, D. (2000). Champions of a cause. Teaching PreK-8, 30(5), 6.

Ryan, K. (1995). The ten commandments of character education. The School Administrator, 52(8), 18-19.

Ryan, K. \& Bohlin, K. (2001). Now more than ever, help kids build character. Education Digest, 67(3), 8-15. 
Ryan, K., Bohlin, K.E., \& Thayer, J.O. (1996). Character education manifesto. Retrieved from

http://www.bu.edu/ccsr/about-us/partnerships/character-education-manifesto/ Salls, H.S. (2007). Character education: transforming values into virtue. Lanham :

University Press of America.

Schaps. E. \& Lewis, C. C. (1998). Breeding citizenship through community in school. The School Administrator, 55(5), 22-24.

Schein, E. H. (1992). Organizational culture and leadership. San Francisco: Jossey-Bass.

Sockett, H. \& Alston, K. (1989). Courage, friendship and character education (Report No. EA-021-009). San Francisco, CA: American Educational Research Association. (ERIC Document Reproduction Service No. ED 307 692)

Thomas, R. S. (1998). Assessing character education: Paradigms, problems, and potentials. Retrieved December 18, 2011, from http://www.quest.edu/wnarticles2.htm.

Tyree, C., Vance, M. \& McJunkin, M. (1997). Teaching values to promote a more caring world: A moral dilemma for the $21^{\text {st }}$ century. Journal for a Just and Caring Education, 3(2), 215-226.

Vessels, G. G. \& Boyd, S. M. (1996). Public and constitutional support for character education. NASSP Bulletin, 80(579), 55-62.

Wynne, E.A. (1988). Balancing character development and academics in the elementary school. Phi Delta Kappan, 69(6), 424-426. 
VITA

Paul E. Sharp II was raised and lived in Beech Grove, IN from infancy to a young adult. During this time he graduated from Beech Grove High School and completed his undergraduate studies at Indiana University-Bloomington earning degrees in both Political Science and History Education.

His professional teaching career started in Perryville, MO teaching $7^{\text {th }}$ grade social studies and government. During this time he studied and earned a Master's in Educational Administration from Southeast Missouri State University in Cape Girardeau, MO.

Sharp's administrative career began in 2000 as an assistant middle school principal in Sikeston, MO. This was followed by administrative positions at Scott City Middle School in Scott City, MO, and Sperreng Middle School and Bayless Junior High/Middle School, both in St. Louis County.

At the time of the completion of this paper, Paul Sharp had left education to pursue other opportunities, never fully closing the door on a return. 